\title{
PENGARUH ATRIBUT, KEPERCAYAAN KONSUMEN, DAN NILAI YANG DIPERSEPSIKAN TERHADAP INTENSI PEMBELIAN
}

\author{
Jennyvia Cintammy dan Frangky Slamet \\ Program Studi Manajemen, Fakultas Ekonomi dan Bisnis, Universitas Tarumanagara Jakarta \\ Email: jennyvia.cintammy@gmail.com
}

\begin{abstract}
This study aims to analyze the effect of attributes, consumer trust and perceived value on purchase intentions in organic food in Indonesia. The sample selection technique used in this study was purposive sampling. Researchers distributed questionnaires to 100 respondents. Data analysis uses multiple regression with the SPSS program. Version 25. The results of the analysis conclude that the attributes, consumer trust and perceived value simultaneously or partially influence the purchase intention.
\end{abstract}

Keywords: attributes, consumer trust, perceived value and purchase intentions.

Abstrak: Penelitian ini bertujuan untuk menganalisis pengaruh atribut, kepercayaan konsumen dan nilai yang dipersepsikan terhadap intensi pembelian pada makanan organik di indonesia. Teknik pemilihan sampel yang digunakan pada penelitian ini adalah purposive sampling. Peneliti menyebarkan kuesioner kepada 100 responden. Analisis data menggunakan regresi ganda dengan program SPSS. Versi 25. Hasil analisis menyimpulkan bahwa atribut, kepercayaan konsumen dan nilai yang dipersepsikan secara simultan maupun parsial berpengaruh terhadap intensi pembelian.

Kata kunci: atributs, kepercayaan konsumen, nilai yang dipersepsikan, intensi pembelian.

\section{LATAR BELAKANG}

Saat ini tumbuh kesadaran tentang masalah lingkungan dan implikasi kesehatan terkait perubahan pola konsumsi. Konsumsi buah-buahan dan sayuran organik menjadi populer karena dikaitkan dengan kesehatan dan kesejahteraan (Krystallis dan Chryssohoidis, 2005; First dan Brozina, 2009). Kesadaran masyarakat terhadap kelestarian lingkungan dan kesehatan yang terus meningkat sekarang ini, menyebabkan sebagian masyarakat mulai melirik untuk mengkonsumsi produk makanan dengan mempertimbangkan tingkat keamanan (food safety atributes), kandungan gizi (nutritional attributes) dan label ramah lingkungan (eco-labelling attributes) (Rusma dkk., 2011). Hal ini memperkuat keinginan dan kebutuhan konsumen untuk mendapatkan produk yang cocok pada lingkungan saat ini. Salah satunya dengan mengonsumsi makanan organik (organic food) atau disebut dengan segmen "green market".

Makanan sehat akan memberikan pengaruh pada penormalan tubuh biologis, fungsi fisiologis atau mempertahankan kesejahteraan tubuh manusia (Lu dan Hsu, 2006). Ahmad dan Juhdi (2008) mencatat bahwa persepsi terhadap makanan organik mempengaruhi perilaku konsumen pro-lingkungan. Tingginya tingkat kekhawatiran lingkungan disebabkan karena masalah kesehatan (Kata et al., 2003). Keyakinan tentang keamanan produk, dan keramahan produk terhadap lingkungan mempengaruhi perilaku konsumen pro-lingkungan (Ahmad dan Juhdi, 2008). 
Keamanan pangan menjadi salah satu hal penting untuk makanan. Ketakutan terhadap kualitas makanan telah meningkat beberapa tahun belakangan ini yang mencakup pembelian makanan dan aspek-aspek pertanian (Buszby, 2001). Banyak penyakit yang beredar bersumber dari makanan di mana konsumen kurang menyadari makanan yang biasa dikonsumsi kemungkinan tidak bersih atau tidak tidak sehat. Kurangnya perhatian terhadap hal ini sering berdampak pada kesehatan, contohnya adalah keracunan makanan akibat tidak bersihnya proses pengolahan sampai dengan penyajiannya dan penggunaan bahan kimia berbahaya yang berisiko menimbulkan penyakit bahkan mengakibatkan kematian. Saat ini, keamanan pangan telah menerima perhatian lebih dari sebelumnya oleh pemerintah dan pembuat kebijakan, profesional kesehatan, industri makanan, masyarakat biomedis serta masyarakat secara umum (Magkos, Arvaniti, Zampelas, 2006).

Faktor terpenting yang menentukan pertumbuhan pasar untuk makanan dan minuman organik adalah meningkatnya minat konsumen terhadap masalah kesehatan dan lingkungan (Davies dkk., 1995). Minat terhadap pembelian makanan organik dipengaruhi oleh sikap konsumen terhadap makanan organik itu sendiri (Michaelidou \& Hassan, 2008). Vermeir \& Verbeke (2006) menyatakan bahwa meskipun sikap konsumen positif terhadap makanan organik namun pola perilaku konsumen terhadap makanan organik tidak konsisten.

Berkenaan dengan produk organik, niat pembelian (purchase intention) dapat dipengaruhi oleh beberapa elemen, seperti masalah kesehatan, kesadaran lingkungan, ketersediaan produk, kualitas yang dirasakan, distribusi produk, nilai gizi, dan lain-lain. Rana dan Paul (2012) menunjukkan bahwa tidak hanya faktor kesehatan yang mempengaruhi niat beli, tetapi juga ketersediaan dan kualitas produk. Iyer, Davari, dan Paswan (2016) mempelajari hubungan antara niat beli dan variabel seperti harga, nilai, kesadaran sosial, dan kesadaran lingkungan dari produk hijau. Namun, hasil penelitian Yadav dan Pathak (2016) memperlihatkan bahwa hanya kesadaran lingkungan yang secara langsung terkait dengan niat pembelian, Mengingat bahwa pilihan makanan konsumen merupakan hasil dari proses kompleks yang dipengaruhi oleh beberapa faktor (Costell, Tarrega, \& Bayarri, 2010), diperlukan untuk pemeriksaan terhadap banyak faktor yang mempengaruhi keputusan konsumen untuk membeli makanan organik, seperti atribut dari makanan organik itu sendiri.

Menurut beberapa penelitian, kesehatan adalah salah satu atribut utama untuk mengkonsumsi makanan organik, seperti yang ditunjukkan oleh Loebnitz dan AschemannWitzel (2016) dan Thogersen, Barcellos, Peirin, dan Zhou (2015). Selain manfaat kesehatan, Thogersen dkk. (2015) menyoroti pentingnya rasa dan kepedulian lingkungan dalam sikap konsumen yang membeli produk organik. Roitner-Schobesberger, Darnhofer, Somsook, dan Vogl (2008) melakukan penelitian di Bangkok dan menekankan bahwa, bersama dengan manfaat kesehatan, permintaan untuk produk baru, "trendi" dan lebih enak adalah prediktor penting dari konsumsi makanan organik.

Kepercayaan konsumen (consumer trust) didefinisikan sebagai keyakinan, perasaan, atau harapan tentang kesetiaan mitra dagang, yang dihasilkan dari niat, integritas, atau kompetisinya (Moorman, Zaltman, \& Deshpande, 1992). Kepercayaan pada makanan organik sulit untuk dinilai. Hal ini disebabkan oleh tidak adanya karakteristik produk yang terlihat pada saat pembelian, sehingga konsumen hanya dapat mengandalkan segel dan sertifikasi yang ditandai pada produk (Kohlraush, Campos, \& Selig, 2004). Menurut Schlosser (2006), menyatakan bahwa kepercayaan konsumen adalah penentu intensi pembelian. Jika pembeli sudah memiliki kepercayaan pengalaman dengan penjual, mereka akan memiliki tingkat intensi pembelian yang lebih tinggi.

Dalam ulasan oleh Shaharudin, Pani, Mansor, dan Elias (2010), nilai yang dipersepsikan (perceived value) dari makanan organik juga terkait dengan nutrisi yang ada dalam produk, keamanan, rasa, dan harga premium. Sebagian besar konsumen bersedia membayar harga yang lebih tinggi untuk mendapatkan bebagai manfaat dan nutrisi akan 
makanan organik. Singh dan Verma (2017) menyelidiki faktor-faktor yang mempengaruhi pembelian makanan organik oleh konsumen di India dan di antara mereka mengatakan bahwa harga yang dipersepsikan memiliki efek yang positif akan niat beli mereka.

\section{KAJIAN TEORI}

Kotler (2005, h. 205) menggagas pernyataan bahwa intensi pembelian adalah sesuatu yang timbul setelah menerima rangsangan dari produk yang dilihatnya. Dari sana timbul ketertarikan untuk mencoba produk tersebut sampai pada akhirnya timbul keinginan untuk membeli agar dapat memilikinya. Pengertian lain juga dijelaskan oleh Schiffman dan Kanuk (2007, h. 228) yang berpendapat bahwa intensi pembelian merupakan suatu model sikap seseorang terhadap objek barang yang sangat cocok dalam mengukur sikap terhadap golongan produk, jasa, atau merek tertentu.

Menurut Keller (1993, h. 27) dalam pandangan luas atribut produk adalah fitur deskriptif yang bertujuan untuk mengkarakteristik sebuah produk. Sedangkan menurut Kotler dan Armstrong (2004, h. 347 ), atribut produk adalah pengembangan atas suatu produk yang melibatkan penentuan manfaat yang akan diberikan.

Menurut Ganesan (1994); Hart dan Saunders (1997) kepercayaan adalah tingkat kesediaan untuk bergantung pada suatu objek berdasarkan harapan kemampuan, keandalan dan kebajikannya. Morgan dan Hunt (1994) mendefinisikan kepercayaan sebagai kepercayaan pada keandalan dan integritas mitra pertukaran. Mereka menjelaskan bahwa keandalan dan integritas dikaitkan dengan konsistensi, kompetensi, kejujuran, keadilan, tanggung jawab, menolong, dan kebajikan. Pengertian lain juga dijelaskan oleh Moorman, Zaltman, dan Deshpande (1992) yaitu kepercayaan konsumen adalah keyakinan, perasaan, atau harapan tentang kesetiaan mitra dagang, yang dihasilkan dari niat, integritas, atau kompetensinya.

Menurut Bolton dan Drew (1991), Patterson dan Spreng (1997) nilai yang dipersepsikan didefinisikan sebagai evaluasi keseluruhan konsumen atas manfaat bersih suatu produk atau jasa berdasarkan penilaian konsumen. Zeithaml (1988, h. 14) mengatakan bahwa nilai yang dipersepsikan adalah perbandingan antara apa yang konsumen berikan atau bayar untuk suatu produk atau jasa dan apa yang dia terima sebagai imbalan. Dengan kata lain, nilai yang dipersepsikan adalah trade-off atau rasio antara harga dan kualitas atau manfaat lain yang ditawarkan oleh merek (Monroe, 1990, h. 51).

\section{Kaitan Antar Variabel}

\section{Kaitan antara Atribut dan Intensi Pembelian}

Hasil penelitian Ko, dkk. (2012) mengenai intensi pembelian berulang terhadap produk jeans menjelaskan bahwa atribut produk yang dibagi menjadi intrinsic attributes dan extrinsic attributes sama-sama berpengaruh tetapi berdampak tidak sama terhadap intensi pembelian berulang.

Hal ini sejalan dengan yang dikemukakan oleh Holak (1990) dan Ho dan Wu (2011) yang menyatakan bahwa intensi pembelian sebagian besar dipengaruhi oleh atribut dan consumer traits.

Berdasarkan uraian tersebut maka dapat disimpulkan bahwa atribut berpengaruh positif terhadap intensi pembelian.

\section{Kaitan antara Kepercayaan Konsumen dan Intensi Pembelian}

Schlosser dkk. (2006) menyatakan bahwa kepercayaan konsumen adalah penentu intensi pembelian. Jika pembeli sudah memiliki kepercayaan pengalaman dengan penjual, mereka akan memiliki tingkat niat beli (purchase intention) yang lebih tinggi. Menurut Park 
dan Kim (2016) kepercayaan konsumen dapat menjadi kontributor penting untuk intensi pembelian konsumen. Kepercayaan konsumen telah didirikan sebagai prediktor kritis untuk hasil positif dari pemasaran dan branding seperti kesetiaan, consumer retention, dan intensi pembelian (Kang dan Hustvedt, 2014).

Hasil penelitian Ma dkk., (2012) menunjukkan bahwa kepercayaan konsumen mengenai konsep perdagangan yang adil terhadap atribut produk memainkan peran penting dalam mengarahkan intensi pembelian.

Berdasarkan hasil uraian di atas dapat disimpulkan bahwa kepercayaan konsumen berpengaruh positif terhadap intensi pembelian.

\section{Kaitan antara Nilai yang Dipersepsikan dan Intensi Pembelian}

Berdasarkan penelitian yang dilakukan Kardes, dkk. (2004) nilai yang dipersepsikan dari suatu produk yang terlihat sebagai sinyal kepada mereka akan secara positif mempengaruhi intensi pembelian konsumen karena penilaian konsumen sering didasarkan pada informasi yang tidak lengkap.

Ini juga sejalan dengan Chang dan Chen (2008) yang mengatakan bahwa jika konsumen merasa bahwa nilai yang dipersepsikan lebih tinggi, mereka lebih cenderung untuk membeli produk.

Dengan demikian, Cronin, dkk. (1997), Patterson dan Spreng (1997), Brady dan Robertson (1999), Eggert dan Ulaga (2002), Tam (2004) menunjukkan bahwa nilai yang dipersepsikan pelanggan berdampak positif terhadap intensi pembelian mereka.

Dari pernyataan di atas maka dapat disimpulkan bahwa terdapat nilai yang dipersepsikan berpengaruh positif terhadap intensi pembelian.

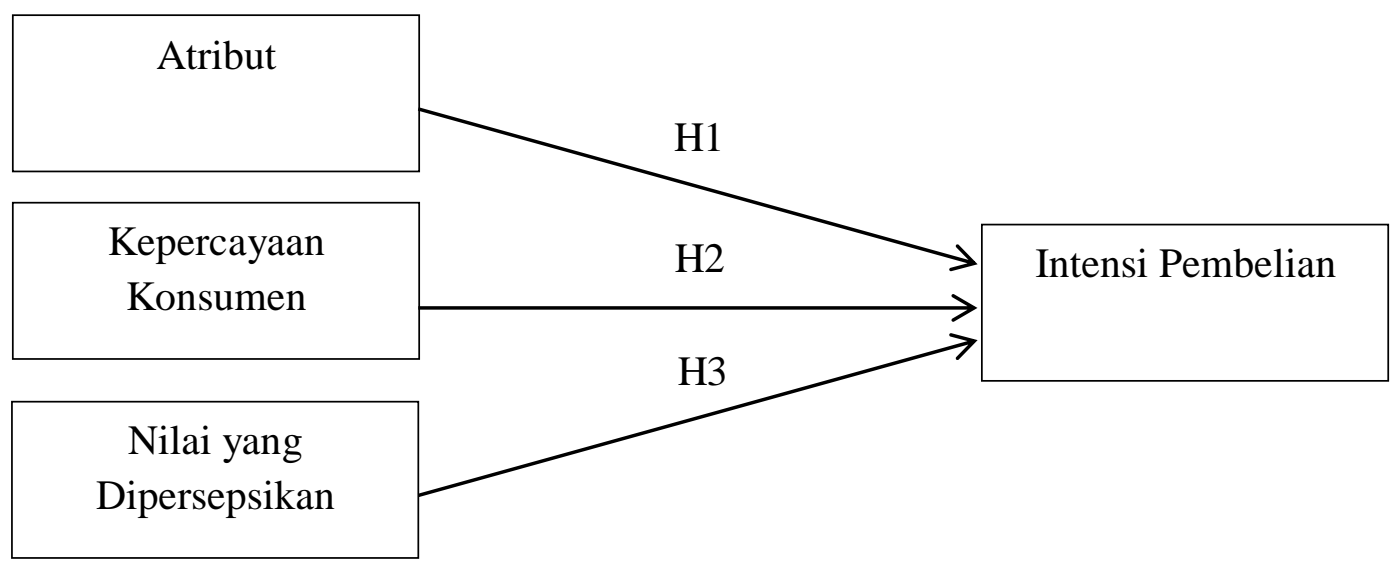

Gambar 1

Kerangka Pemikiran

Hipotesis dalam penelitian ini adalah sebagai berikut.

$\mathrm{H}_{1}$ : Atribut berpengaruh positif terhadap intensi pembelian

$\mathrm{H}_{2}$ : Kepercayaan berpengaruh positif terhadap intensi pembelian

$\mathrm{H}_{3}$ : Nilai yang dipersepsikan berpengaruh positif terhadap intensi pembelian

\section{METODE PENELITIAN}

Penelitian ini, menggunakan metode deskriptif dan kuantitatif berdasarkan data yang didapat melalui kuesioner dengan pembagian kuesioner menjadi beberapa tahap yaitu mengenai atribut, kepercayaan konsumen dan nilai yang dipersepsikan menurut konsumen makanan organik di Indonesia. Populasi dari penelitian ini adalah para konsumen makanan organik di 
Indonesia. Teknik pemilihan sampel yang digunakan pada penelitian ini adalah purposive sampling Jumlah responden yang akan diambil dalam penelitian ini adalah 100 responden dikarenakan adanya keterbatasan-keterbatasan yang dimiliki

\section{HASIL UJI STATISTIK}

\section{Deskrispi Subyek Penelitian}

Jumlah responden yang berpartisipasi berjenis kelamin perempuan yaitu sebanyak 57 responden $(57 \%)$ sedangkan responden laki-laki sebanyak 43 responden (43\%). Mayoritas responden berusia 20 - 25 tahun yaitu sebanyak 72 responden (72\%), yang berusia kurang dari 20 tahun sebanyak 19 responden (9\%), berusia 26-35 tahun sebanyak 3 responden (3\%), berusia 36-50 tahun sebanyak 2 responden dan berusia lebih dari 50 tahun sebanyak 4 responden (4\%). Pekerjaan yang mendominasi responden adalah pelajar/mahasiswa yaitu sebanyak 65 responden (65\%), karyawan/karyawati sebanyak 14 responden (14\%), wirausaha sebanyak 18 responden (18) dan sebanyak 3 responden (3\%) merupakan ibu rumah tangga. Mayoritas responden memiliki jenjang pendidikan terakhir SMA yaitu sebanyak 60 responden (60\%), sedangkan sebanyak 19 responden (19\%) memiliki jenjang pendidikan terakhir diploma, lalu S1 sebanyak 9 responden (9\%), dan SMP serta S2 masing-masing sebanyak 6 responden (6\%). Pengeluaran per bulan responden kurang dari Rp. 2.00.000 sebanyak 14 responden (14\%), pengeluaran Rp. 2.000.000-Rp. 5.000.00 sebanyak 51 responden (51\%), pengeluaran Rp. 5.000.000-Rp. 8.000.000 perbulan sebanyak 21 responden (21), pengeluaran Rp. 8.000.000-Rp10.000.000 perbulan sebanyak 10 responden (10\%) dan pengeluaran lebih dari Rp. 10.000 .000 perbulan sebanyak 4 responden (4\%).

\section{Hasil Uji Asumsi Klasik Uji Normalitas}

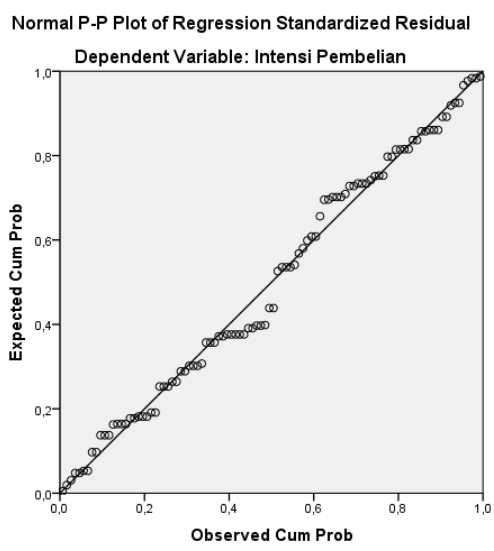

Gambar 2

Hasil Uji Normalitas

Pada gambar 2 dapat dilihat data menyebar di sekitar garis diagonal dan mengikuti arah garis diagonal maka dapat dikatakan bahwa model regresi memenuhi asumsi normalitas.

\section{Uji Multikolinearitas}

Tabel 1

Hasil Pengujian Multikolinearitas

\begin{tabular}{|l|c|c|}
\hline \multicolumn{1}{|c|}{ Variabel } & VIF & Kesimpulan \\
\hline Atribut & 1,166 & Tidak terdapat multikolinearitas \\
\hline Kepercayaan Konsumen & 1,201 & Tidak terdapat multikolinearitas \\
\hline
\end{tabular}




\section{\begin{tabular}{|l|c|c|}
\hline Nilai yang Dipersepsikan & 1,036 & Tidak terdapat multikolinearitas \\
\hline
\end{tabular}}

dapat diketahui bahwa nilai VIF pada atribut sebesar 1.166, nilai VIF pada kepercayaan konsumen sebesar 1.201, nilai VIF pada nilai yang dipersepsikan sebesat 1.036. Hasil uji multikolinearitas menunjukkan bahwa ketiga variabel tersebut memiliki nilai VIF yang lebih kecil dari 10. Dengan demikian ketiga variabel tersebut dinyatakan tidak terdapat multikoliniearitas

\section{Uji Heteroskedastisitas}

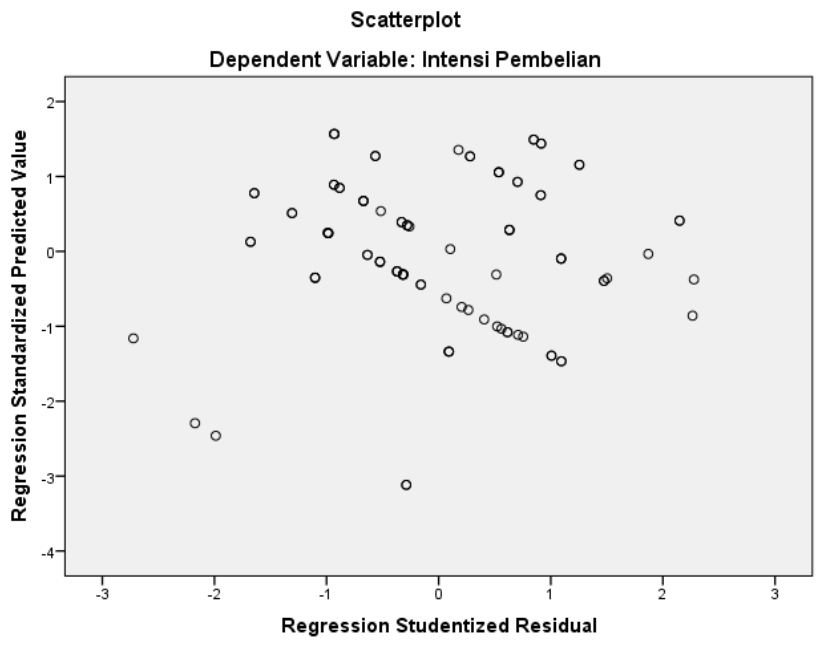

Gambar 3

Hasil Uji Heteroskedastisitas

Berdasarkan hasil uji heteroskedastisitas yang ditunjukkan, dinyatakan tidak terdapat heterokesdastisitas karena titik-titik tidak membentuk pola tertentu dan menyebar.

\section{Analisis Regresi Berganda}

Model yang digunakan untuk menganalisis Stres Kerja (X1), Beban Kerja (X2) dan Lingkungan (X3) terhadap Kinerja Karyawan (Y) adalah analisis regresi linier berganda.

Tabel 2

Analisis Regresi Ganda

\begin{tabular}{|ll|c|r|r|}
\hline Model & & $\begin{array}{c}\text { Unstandardized } \\
\text { Coefficients }\end{array}$ & \multirow{2}{*}{ Sig. } & \\
\cline { 3 - 4 } & & \multicolumn{1}{|c|}{$\mathrm{B}$} & & \\
\hline \multirow{4}{*}{1} & (Constant) & 1,048 &, 685 &, 495 \\
& Atribut &, 241 & 4,841 &, 000 \\
& Kepercayaan Konsumen &, 314 & 8,135 &, 000 \\
& Nilai yang Dipersepsikan &, 247 & 4,073 &, 000 \\
\hline
\end{tabular}

a. Dependent Variable: Intensi Pembelian

Pada Tabel 2 didapat persamaan regresi linier berganda dengan 3 variabel independen sebagai berikut:

$$
\mathrm{Y}=1.048+0.241 \mathrm{AT}+0.314 \mathrm{CT}+0.247 \mathrm{PV}
$$




\section{Pengujian Hipotesis}

Untuk mengetahui apakah persamaan tersebut signifikan atau tidak, maka dilakukan pengujian sebagai berikut:

a. Uji F (ANOVA)

Uji $\mathrm{F}$ ini dimaksudkan untuk mengetahui ada tidaknya pengaruh dari variabel independen terhadap variabel dependen secara bersama-sama (secara simultan). Berikut adalah hasil uji F dengan bantuan SPSS:

Tabel 3

Hasil Uji Ketepatan Model (Uji F)

\begin{tabular}{|c|c|c|c|c|c|}
\hline Model & Sum of Squares & Df & Mean Square & F & Sig. \\
\hline Regression & 207,664 & 3 & 69,221 & 47,315 &, $000^{\mathrm{b}}$ \\
\hline Residual & 140,446 & 96 & 1,463 & & \\
\hline Total & 348,110 & 99 & & & \\
\hline
\end{tabular}

nilai signifikansi sebesar $0.000<\alpha 0,05$ yang berarti setidaknya terdapat satu dari tiga variabel bebas dapat menjadi prediktor terhadap variabel terikatnya secara bersamaan.

\section{Uji t}

Uji-t dilakukan untuk mengetahui secara parsial pengaruh variabel bebas terhadap variabel terikat, di mana dapat diartikan bahwa variabel bebas dalam penelitian ini memiliki pengaruh terhadap variabel terikat dengan asumsi bahwa variabel lainnya itu dianggap konstan (Malhotra, 2010). Tingkat keyakinan yang digunakan yaitu 95\% atau $(\alpha)=0,05$ Apabila nilai signifikansi (sig) $>\alpha$, artinya tidak terdapat pengaruh dari variabel bebas terhadap variabel terikat.

H1: Atribut berpengaruh positif terhadap Intensi Pembelian.

Berdasarkan tabel 2 dapat diketahui bahwa atribut memiliki nilai signifikansi 0.000 yang berarti lebih kecil dari nilai $\alpha=0.05$. Hasil analisis regresi ganda pada tabel 2 dapat digunakan untuk menjawab hipotesis 1 . Nilai signifikansi atribut sebesar 0.000 yang berarti lebih kecil daripada $\alpha 0.05$, sehingga dapat disimpulkan bahwa hipotesis 1 yang menyatakan bahwa atribut berpengaruh positif terhadap intensi pembelian tidak ditolak.

$\mathrm{H} 2$ : kepercayaan konsumen berpengaruh positif terhadap intensi pembelian.

Berdasarkan tabel 2 dapat diketahui bahwa kepercayaan konsumen memiliki nilai signifikansi 0.000 yang berarti lebih kecil dari nilai $\alpha=0.05$. Hasil analisis regresi ganda pada tabel 2 dapat digunakan untuk menjawab hipotesis 2. Nilai signifikansi kepercayaan konsumen sebesar 0.000 yang berarti lebih kecil daripada $\alpha 0.05$, sehingga dapat disimpulkan bahwa hipotesis 2 tidak ditolak.

H3: nilai yang dipersepsikan berpengaruh positif terhadap intensi pembelian.

Berdasarkan tabel 2 dapat diketahui bahwa nilai yang dipersepsikan memiliki nilai signifikansi 0.000 yang berarti lebih kecil dari nilai $\alpha=0.05$. Hasil analisis regresi ganda pada tabel 2 dapat digunakan untuk menjawab hipotesis 3. Nilai signifikansi nilai yang dipersepsikan sebesar 0.000 yang berarti lebih kecil daripada $\alpha 0.05$, sehingga dapat disimpulkan bahwa hipotesis 3 tidak ditolak.

Analisis Koefisien Determinasi $\left(\mathbf{R}^{2}\right)$

Tabel 4

Tabel Koefisien Determinasi

\begin{tabular}{|c|c|}
\hline Model & R Square \\
\hline 1 & 0.597 \\
\hline
\end{tabular}


Nilai $\mathrm{R}^{2}$ yaitu sebesar 0.597 yang artinya sebesar $59.7 \%$ variabel terikat dapat dijelaskan oleh ketiga variabel bebas, sedangkan sisanya dapat dijelaskan oleh variabel variabel lain selain keempat variabel bebas tersebut.

\section{DISKUSI}

Berdasarkan pengujian regresi dalam penelitian ini dapat disimpulkan bahwa hipotesis 1 tidak ditolak yang menyatakan bahwa atribut berpengaruh positif terhadap intensi pembelian makanan organik. Hasil ini dapat diartikan bahwa hipotesis 1 didukung oleh data dan sejalan dengan teori yang dikemukakan oleh oleh Holak (1990) dan Ho dan Wu (2011) yang menyatakan bahwa intensi pembelian sebagian besar dipengaruhi oleh atribut dan consumer traits. Hal tersebut di dukung oleh penelitian Ko, dkk. (2012) sereta Isabelle dan Eluiza (2018) yang menyatakan bahwa atribut berpengaruh positif terhadap intensi pembelian.

Berdasarkan pengujian regresi dapat disimpulkan bahwa hipotesis 2 tidak ditolak yang menyatakan bahwa kepercayaan konsumen berpengaruh positif terhadap intensi pembelian makanan organik. Hasil ini dapat diartikan bahwa hipotesis 2 didukung oleh data. Hal ini terjadi karena Jika pembeli sudah memiliki kepercayaan pengalaman dengan penjual, mereka akan memiliki tingkat niat beli (purchase intention) yang lebih tinggi.. Hasil ini sesuai dengan teori yang dikemukakan oleh Schlosser dkk. (2006) menyatakan bahwa kepercayaan konsumen adalah penentu intensi pembelian.

Berdasarkan pengujian regresi dapat disimpulkan bahwa hipotesis 3 tidak ditolak yang menyatakan bahwa nilai yang dipersepsikan berpengaruh positif terhadap intensi pembelian makanan organik. Hasil ini dapat diartikan bahwa hipotesis 3 didukung oleh data. Hal dapat diartikan bahwa responden memiliki loyalitas dalam bentuk niat mereka untuk membeli atau merekomendasikan makanan organik kepada orang lain. Hasil ini sesuai dengan teori dikemukakan oleh Kardes, dkk. (2004) nilai yang dipersepsikan dari suatu produk yang terlihat sebagai sinyal kepada mereka akan secara positif mempengaruhi intensi pembelian konsumen karena penilaian konsumen sering didasarkan pada informasi yang tidak lengkap.

\section{PENUTUP}

\section{Kesimpulan}

Berdasarkan penelitian dan pembahasan, maka dapat diambil beberapa kesimpulan sebagai berikut:

1. Atribut berpengaruh positif terhadap intensi pembelian makanan organik.

2. Kepercayaan konsumen berpengaruh positif terhadap intensi pembelian makanan organik.

3. Nilai yang dipersepsikan berpengaruh positif terhadap intensi pembelian makanan organik.

\section{Saran}

Setelah meneliti dan mengetahui permasalahan yang ada, maka saran yang dapat diberikan bagi perusahaan dan bagi peneliti lain yaitu:

1. Disarankan kepada pihak pemasar produk organik agar meningkatkan strategi pemasaranya yang berhubungan dengan unsur-unsur yang melekat pada produk organik dengan menambah atribut produk yang sesuai dengan selera konsumen sehingga intensi pembelian produk organik lebih tinggi. 
2. Disarankan bagi pemasar produk organik untuk dapat meningkatkan kepercayaan konsumen akan produk organik melalui penyebaran informasi terkait kualitas dari produk organik dari pada produk konvensional. Pemasar produk organik sebaiknya menjaga kualitas produk dengan cara menjamin kebersihan produk dan mengemas produk untuk menjaga higienitasnya sebelum didistribusikan, sehingga konsumen merasa puas yang akhirnya akan melakukan pembelian terhadap produk organik.

3. Disarankan bagi pemasar produk organik untuk meningkatkan nilai yang dipersepsikan oleh konsumen, sehingga dapat menimbulkan intensi pembelian, karena melalui penelitian ini nilai yang dipersepsikan berpengaruh positif terhadap intensi pembelian produk organik.

\section{DAFTAR PUSTAKA}

Ahmad, S. N. B., \& Juhdi, N. (2008). Organic Food: A Study on Demographic Characteristics and Factors Influencing Purchase Intentions Among Consumers in Klang Valley, Malaysia. International Journal of Business and Management, 5(2), $105-118$

Bolton, R. N., and J. H. Drew. (1991). A multistage model of customers' assessments of service quality and value. Journal of Consumer Research 17 (4): 375-384

Buzby, J,C., (2001). Effects of Food-Safety Perceptions on Food Demand and Global Trade, In: Regmi, A. 2001. Ed., Changing Structure of Global Food Consumption and Trade, Washington DC: United States Departement of Agriculture (USDA), Economic Research Service. 65 (2), pp. 55-66

Chen, C. F dan Y. Y. Chang, (2008). Airline Brand Equity, Brand Preference and Purchase Intentions The Moderating Effects of Switching Costs, Journal of Air Transport Management, 14(6): 40-42

Costell, E., Tárrega, A. and Bayarri, S. (2010) Food Acceptance: The Role of Consumer Perception and Attitudes. Chemosensory Perception, 3, 42-50.

Davies, A., Titteington, A. and Cochrane, C. (1995). Who buy organic food? A profile of the purchasers of organic food in Northern Ireland. British Food Journal, Vol. 97 (10), $17-23$.

Ganesan, S. (1994), "Determinant of Long-Term Orientation in Buyer-Seller relationship,". Journal of Marketing. Vol. 58, pp. 1-19.

Ho, C. H., dan Wu, T. Y. (2011). Factors Affecting Intent to Purchase Virtual Goods in Online Games. International Journal of Electronic Business Management, 10 (5): 204-212.

Holak. (1990). Purchase Intentions and The Dimensions of Innovation : An Explatory Model. Journal of Product Innovation Management, 12 (4) : 56-69

Iyer, P., Davari, A., \& Paswan, A. (2016), Green products: altruism, economics, price fairness and purchase intention. Social Business, 6(1), 39-64.

Kardes, FR. (2004). Consumer Behavior and Managerial Decision Making. Second Edition. Prentice-Hal of India, New Delhi.

Kata, et.al. (2003). Quality of Organic Animal Products. Livestock Production Science. 80 (2) $15-30$

Kohlraush, A. K., Campos, L. M. d. S., \& Selig, P. M. (2004). Selos ambientais: qual seu papel e influência no processo de compra de produtos orgânicos. Proceedings of the $24^{\circ}$ Encontro Nacional de Engenharia de Produção[ENEGEP], Florianópolis.

Kotler, Philip dan Armstrong. (2004). Dasar-Dasar Pemasaran. Jakarta: Indeks

Kotler, Philip. (2005). Manajemen Pemasaran. Jilid 1 dan 2. Jakarta : Indeks Kelompok Gramedia 
Krystallis, A., \& Chryssohoidis, G. (2005). Consumers' willingness to pay for organic food: factors that affect it and variation per organic product type. British Food Journal, 107(5), 320-343.

Loebnitz, N., \& Aschemann-Witzel, J. (2016). Communicating organic food quality in China: consumer perceptions of organic products and the effect of environmental value priming. Food Quality and Preference, 50,102-108.

Magkos, F., Arvaniti, F., Zampelas, A..(2006), Organic Food: Buying More Safety or Just Peace of Mind? A Critical Review of the Literature, Critical Reviews in Food Science and Nutrition, 46. (1), pp. 23-56

Michaelidou, N. dan Hassan, L. M. (2008). The Role of Health Consciousness foods safety concern and ethical identity on attitudes and intention towards organic foods, International Journal of Consumer Studies, 32: 163-170

Moorman, Christine, Rohit Deshpande, dan Gerald Zaltman. (1992). "Factors Affecting Trust in Market Research Relationships". Journal of Marketing. 57 (5). pp 81-101

Morgan, R.M. and Hunt, S.D. (1994), The commitment-trust theory of relationship marketing, Journal of Marketing, 58 (3), pp. 20-38

Ottman, J.A. (2000). "It's not just the environment, stupid". Retrieved Juni, 2020, downloadable at http://www.greenmarketing.com/articles/IB Sept00.html

Park, Chung-Hoon, and Young-Gul Kim. (2016). "The Effect of Information Satisfaction and Relational Benefit on Consumers Online Site Commitmennts". Journal of Electronic Commerce in Organizations, 4(1), 70 - 90

Patterson, P. G. and R. A. Spreng. (1997). Modelling the relationship between perceived value, satisfaction and repurchase intentions in a business-to-business, services context: An empirical examination. International Journal of Service Industry Management 8 (5): 414-434

Rana, J., \& Paul, J. (2012). Consumer behavior and purchase intention for organic food. Journal of Consumer Marketing, 29(6), 412-422.

Rusma J, Hubeis M, dan Suharjo B. (2011). Kajian preferensi konsumen rumah tangga terhadap beras organik di wilayah Kota Bogor. Manajemen IKM. Vol 6 (1).

Schiffman, Leon.G. dan Leslie Lazar Kanuk. (2007). Perilaku Konsumen. Edisi Ke-7. Diterjemahkan oleh Zoelkifli Kasip. Jakarta: Indeks,

Shaharudin, M. R., Pani, J. J., Mansor, S. W., \& Elias, S. J. (2010). Purchase intention of organic food: perceived value overview. Canadian Social Science, 6(1), 70-79.

Singh , K dan Verma, N (2017). Author Productivity and Degree of Collaboration in Journal of Librarianship and Information Science (JOLIS) 2010 - 2016. International Journal of Library and Information Studies, 7 (4) : 1-6.

Thøgersen, J., Barcellos, M. D., Perin, M. G., \& Zhou, Y. (2015). Consumer buying motives and attitudes towards organic food in two emerging markets: China and Brazil. International Marketing Review, 32(3/4), 389-413.

Vermeir, Iris and Wim Verbeke (2006) Sustainable food consumption: exploring the consumer 'attitude - behavioral intention' gap, Journal Of Agricultural \& Environmental Ethics. 19(2). p.169-194

Waskito, Danang, M. Ananto Z, dan Andre Rezza S.P. (2014). Persepsi Konsumen Terhadap Makanan Organik Di Yogyakarta.

Zeithaml, A. Parasuraman, Valarie A. and Leonard L. Berry. (1988). "SERVQUAL: A Multiple-Item Scale for Measuring Consumer Perceptions of Service Quality”. Journal of Retailing. Vol 64 (1) pp 12-37 